\title{
Waqf Land in the West Bank and Investment Current State of Affairs
}

\author{
Anwar H. M. Musaee ${ }^{1,2}$, Eeman Muhammad Abbas ${ }^{1}$, Wan Kamal Mujan ${ }^{1} \&$ Roziah Sidik@ Mat Sidek ${ }^{1}$ \\ ${ }^{1}$ Department of Arabic Studies and Islamic Civilization, Faculty of Islamic Studies, National University of \\ Malaysia, Bangi, Selangor, Malaysia \\ ${ }^{2}$ Ministry of Education, Palestine \\ Correspondence: Anwar H. M. Musaee, Ministry of Education, Palestine. E-mail: anwarmusaee1@gmail.com
}

Received: February 18, 2014 Accepted: May 9, 2014 Online Published: June 24, 2014

doi:10.5539/ass.v10n14p23 URL: http://dx.doi.org/10.5539/ass.v10n14p23

\begin{abstract}
This study has sought to find out the total area of waqf land in the West Bank, in terms of its types, and the efficiency of its investment. To these two ends, the researcher has tackled three major tracks: total area of waqf land in the West Bank; reality of its exploitation in the West Bank governorates; and efficiency of its investment. During his investigation, the researcher faced tremendous difficulties. On the theoretical side, and since the advent of the Palestinian National Authority, there has been a dearth of literature on these three tracks and on the investment of waqf land in the West Bank in particular. On the practical side, there was not a database available on this waqf land with the directorates of waqf. The researcher only managed to access some statistical publications and paper records. Therefore, he found himself compelled to process more than 2,800 files archived by the directorates of the waqf. He also conducted a number of personal interviews to identify the type of land and extent of its validity or suitability for investment. After collection of this data, he computed it and made an analysis of results according to type, geographical location, percentage of its occupancy using the analytical descriptive method. After data analysis, it was found that the West Bank was home to a treasure of waqf land but unfortunately it was not exploited well. The waqf land was found to be of two types. The first one is appropriate for all kinds of investment and it includes plain lands (92\%), planted lands (4.1\%) and land invested for real estate $(1.2 \%)$. The second one is land that has been allocated for public benefit. This includes cemeteries, mosques and holy shrines (maqams). This type represents $2.7 \%$. The results also showed that the percentage of plain land leased was very low. It did not exceed $1.6 \%$ of the total area of plain land in the West Bank. In contrast, the planted land amounted to more than $50 \%$. This was due to the fact that the lease was used to being concluded seasonally. Undoubtedly, this poor exploitation of land has had negative effects on the revenues of waqf property and on the extent of its contribution to the Palestinian gross national product and maintenance of food security. The religious and historical shrines in the West Bank were found to be in very poor physical conditions, thus making the premises unsuitable for use. This poor physical condition of the shrines shows how much they have been neglected over the years. In the light of these findings, the study concluded with a number of recommendations, which, if taken seriously, could advance the waqf land sector. There is a necessity to make active use of unused waqf land and invest it anew in vital fields.
\end{abstract}

Keywords: waqf, West Bank, Palestine, Islamic endowment, economic policy, waqf lands

\section{Introduction}

Muslim countries, in general, face big challenges when it comes to investment of waqf properties due to the inefficiency of the waqf apparatus (the Ministry of Waqf), its failure in tapping the potentials of waqf, investment in the unused wealth and revival of the waqf tradition. This paper seeks to assess the volume of waqf land, in the first place, and then diagnose the reality of its investment in the Palestinian National Authority's controlled areas, evacuated by the Israeli occupation forces, and the establishment of a national institution to run the waqf property, in the second place.

This paper primarily examines one of the waqf property assets: waqf land of all types in the West Bank. This land was found to be of two types: leased plain land and non-leased plain land. This is in addition to lands belonging to mosques, shrines, and cemeteries (two types of cemeteries: closed and active). The researcher also identified the lands which were economically feasible: plain land and planted land. The lands of mosques, cemeteries and shrines were classified as public utility and charitable work. 
The researcher first analyzed the descriptive data of this land in every governorate in the West Bank. Then he tabulated the results in separate tables. This was done in order to provide a logical diagnosis of the waqf land area and percentage of the investment of each type, thus helping in the creation of an official database that could be depended on in any future investment plan for these unused waqf holdings.

\subsection{Problem of the Study}

This study sought to answer the following questions:

1) What is the size of waqf land in every West Bank governorate?

2) What are the types of waqf land?

3) What is the percentage of exploitation of each type of waqf land?

4) What causes are impeding the investment of much of this waqf land?

5) How much efficient is investment in this waqf land?

\subsection{Significance of the Study}

The significance of this study stems from the fact that it is as a continuation of what other researchers had concluded in other studies in examining the waqf land as one of the productive sectors in the Palestinian economy and directly from its primary sources records of the Ministry of Waqf and its directorates. Therefore, this study seeks to create a coherent comprehensive database based on statistical analyses and realistic interpretation, thus bridging the gap of imbalance in the total area of waqf land, and in diagnosis of its investment current state of affairs. This database would become a launching pad for the beginning of building an investment strategy for this vital sector.

\subsection{Objectives of the Study}

This study aimed at finding out the total area of waqf land in the West Bank, its types, and percentage of exploitation of each type. The study also sought to infer the factors which influence the development of this sector and diagnose reality of investment efficiency of these waqf assets.

\subsection{Limitation of the Study}

This study covered all waqf land in the West Bank, Palestine. The field of research covered the lands that are appropriate for agricultural and real estate investment. In this context we talk about 166,214 dunams distributed in the governorates of West Bank. The West Bank is divided into thirteen governorates: Jenin, Tubas, Nablus, Salfit, Tulkarm, Qalqilya, Ramallah, Jerusalem Suburbs, Bethlehem, Jericho, Hebron, Dora and Yatta. The study examined all waqf land between 1994-2013. It's worth noting here that the year 1994 marks the advent of the Palestinian National Authority and its control of waqf property.

\subsection{Definition of Terms}

The West Bank: Geographically, the West Bank is the remaining part of historical Palestine and its area is 5,844 square kilometers. It represents around $21 \%$ of historical Palestine. It was annexed by the Jordanian regime in 1948. In 1967, it became under the Israeli military occupation which lasted until 1994 in the wake of signing the Israeli-Palestinian peace agreements. Since 1994, it has been administered by the Palestinian National Authority.

Governorate: This is a geographical administrative division of a country and it includes the city, the neighboring villages, camps, and lands surrounding them. This is according to local government zoning map.

Waqf: This is an endowment created by the dedication of property in the form of land and other revenue-yielding sources for a charitable public cause or for support of a donor's family.

Plain land: It is land that has neither trees nor buildings. It is either exploited agriculturally or is not suitable for agriculture.

Muzara'ah: This is a share-cropping agreement between the Ministry of Waqf and one farmer who is allowed to farm the land in return for a part of the produce of the land in accordance with what has been agreed upon in the contract. This farming is usually seasonal for one or two agricultural cycles.

Mugharasah: Similar to muzara'ah, mughrasah is an implantation contract in which one party (the land owner) permits the use of its land to be planted and tended fruit bearing trees and the other party (worker or farmer) to do the planting and tending. The harvest is share on the basis of a pre-agreed upon ratio. The contract duration is limited.

Disused cemeteries: These are cemeteries that have been shut down for the last 50 years. Therefore, they can be 
leveled and used for different purposes.

Al-Ihkar: This hoarding of waqf property is a tenancy according to which the waqf remains in the hands of the tenant, known as the hoarder, as long as he pays the rental.

Waqf investment. This refers to every effort (intellectual and financial) the waqf administration makes in order to preserve and develop the waqf holdings legally and in accordance with the Islamic Shari'a purposes.

Lease contract. This refers to the process of leasing real estate property, movables and public utilities in return for a rental agreed upon on contracting.

\section{Literature Review}

The Palestinian Ministry of Waqf owns vast areas of waqf lands, both plain and plated. If these areas were invested properly and efficiently, they would contribute to the economic development of the Palestinian National Authority areas. Unfortunately, the Ministry of Waqf's role in making active use of these areas has been weak. This study came against this poor performance of the ministry and a build on previous studies on this subject. This study is mainly concerned with the diagnosis of this reality. This reality has been tackled from different perspectives. Baker (2009) conducted a study to find out the reality of Islamic waqf in the Gaza Strip and the ways of its development and investment in it. He found that a large percentage of the waqf lands had not been developed. He also found the use primitive ways in making use of these lands. The reasons behind this were the red tape in the Ministry of Waqf and inappropriateness of the current laws pertinent to the development of waqf properties. Attiyeh (2010) examined the ways of employing the Islamic waqf for the sake of achieving economic and social development in the northern West Bank. She found that there were many challenges facing the employment of waqf properties for the sake of sustainable economic and social development. These challenges were related to administration and financing. It is worth noting that these two studies were theses and depended for data collection on questionnaire. They fell short of finding out the reality of waqf properties through primary sources: records and files of the Ministry of Waqf. This study is actually the first that examined the state of waqf properties through first-hand information with the purpose of assessing the situation of these properties as it is on the ground and offer suggestions for the improvement of this situation after many decades of negligence.

\section{Method}

In this study the researcher used the analytical descriptive method. He examined all waqf land in detail depending on files and records of the Ministry of Waqf and its directorates in all the West Bank governorates. In this regard, the researcher managed to access 2,800 files: of these, 212 were pertinent to leased plain land; 1,156 files were pertinent to non-leased plain land; 373 files were related to leased planted lands and 204 files were related to non-leased planted lands. This was in addition to hundreds of files which tackled shrines, and cemeteries (both in operation and disused). The researcher also perused all investment agreements and partnerships, concluded with the private sector, and employed them in the context of the study.

Furthermore, the researcher conducted a number of interviews with authorized employees in the Ministry of Waqf and its directorates. Then, the researcher computed all this data and made an analysis using the analytical descriptive method. He also tabulated the results to illustrate and give a comprehensive picture of the investment efforts that have been made to exploit the waqf land. Therefore, it is necessary to point out that all the tables in the study, save Table 15, was prepared by the researcher and represented the results of the statistical analysis of the descriptive data.

\section{Types of Waqf Land in the West Bank}

The waqf land, administered by the Ministry of Waqf nowadays is definitely much less than the lands it had administered in 1967 and before. Michael Dumper estimated the area of the waqf land in the West Bank to be 600,000 dunams (Dumper, 1992). This conservative estimate cannot be taken outright today due to the lack of accurate statistics about the total area of waqf land (Dumper, 1992). This has made the archiving process and documentation of waqf property improvisational and inaccurate. This in turn has resulted in a state of improvisation in estimation of the area of waqf land (Mansour, 2013).

This state of uncertainty is attributed to the successive political circumstances in Palestine and in the West Bank in particular. Over the decades, there have been assaults on waqf land, loss of waqf documents and deeds. A significant portion of waqf land had not been registered officially. There was also an absence of legal clarity of some waqf holdings. Even the Palestinian National Authority has failed to conduct a comprehensive survey of all its waqf lands (Eshtayyeh et al., 2006).

After analysis of the descriptive data of waqf land in the West Bank, it was found that the area of the waqf land 
(of various types) amounted to more than 170,772 dunams. However, this number cannot be taken for granted because the areas of a lot of waqf holdings are unknown and need to be zoned and surveyed. These lands can be classified into the following types.

\subsection{Plain Lands}

The area of these lands in the West Bank amounted to 157,160 dunams (Ministry of Waqf, 2013a) or 92\% of all waqf land in the West Bank. This makes it suitable for all kinds of investment. Jericho governorate is considered the Ministry of Waqf's treasure of plain land. About $92.5 \%$ of all plain land in the West Bank is located in Jericho Governorate (Jericho Waqf Directorate, 2013).

\subsection{Planted Lands}

The area of the waqf planted lands amounts to 7,065 dunams (Ministry of Waqf, 2013b). This represents only $4.1 \%$ of all waqf lands in the West Bank. The majority of these lands are in the northern governorates. These lands are planted with olive trees, fig trees and stone fruits. The increase in the area of planted lands in the West Bank in the last ten years has been due to the Ministry of Waqf's policy to lease plain lands, according to mugharasah contracts, in the West Bank governorates and in Jericho Governorate in particular. The returns from these planted lands were found to be much bigger than those of plain lands.). (Ministry of Waqf, 2013c).

\subsection{Lands Allocated for Building}

These lands are invested in real estate to build high rise buildings for housing, offices, and commercial stores or to build government or private institutions. The area of lands exploited for construction amounted to more than 1,989 dunams or $1.2 \%$ of the total area of waqf lands in the West Bank (Ministry of Waqf, 2013d). It's worth noting here that all governorates have many areas which enjoy strategic locations and are very suitable for real estate investment and other things (Abed, 2013).

\subsection{Lands of Cemeteries}

The West Bank is home to 670 cemeteries and these occupy 3,503 dunams (Ministry of Waqf, 2013e). These lands are earmarked for public interest and charitable deeds and serve the Muslims. Therefore, they can't be listed with other waqf land allocated for investment. However, there are 92 disused cemeteries occupying more than 277 dunams (Abu Sha'ar, 2006). These disused cemeteries are considered a reservoir of plain lands and enjoy a strategic importance for real estate investment particularly for official institutions, thanks to their strategic location. Fifty years ago, these disused cemeteries were in the outskirts of villages and towns and given the horizontal expansion and rezoning of both villages and towns by local government authorities and urban extension, let alone organization of construction and opening of major highways, after the advent of the Palestinian National Authority, these cemeteries have become in the heart of these towns and villages and on highways, thus making them an attraction for investment by both public and private sectors (Mansour, 2013). Given this strategic advantage, one can easily notice that many official institutions have been built on disused cemeteries and in the villages in particular (Abed, 2013).

\subsection{Lands of Holy Shrines}

The West Bank is home to 393 shrines (maqams). Some of these are historic while others are religious. Most of these shrines are located in villages. The area of the holy shrines amounts to more than 391 dunams (Ministry of Waqf, 2013f).These lands are not included within the lands appropriate for real estate and agricultural investment They can only be invested for tourism purposes (Eshtayyeh et al., 2006). Unfortunately, most of the West Bank shrines are in very poor physical conditions. The majority is either demolished or deserted or lack access roads to them. This shows the lack of interest in these shrines. Many of these shrines have been razed to the ground and have become a thing of the past and have been subjected to a lot of assaults (Attiyah, 2010). These shrines should be given serious interest by adopting a tourism strategy. They are under the jurisdiction of more than one ministry including tourism and antiquities and waqf. These shrines can be transformed into natural tourist sites and holy shrines for visits since many of them are located in naturally attractive areas. Renovation of these shrines and their preservation come within the protection of human and Islamic heritage. They are also a witness of the Arab and national identity of Palestine (Eshtayyeh et al., 2006).

\subsection{Lands of Mosques}

Palestine and the West Bank in particular are well known for the large number of mosques they have (Abdullah, 2013). Almost every single quarter in any town or village has at least one mosque. These mosques have a religious and social importance. They are houses for worship. The Ministry of Waqf has a tradition of appointing an imam (prayer leader in mosque) and a caretaker (qayem) and paying them monthly salaries (Attiyah, 2010). 
According to the statistics of General Administration of Mosques of the Ministry of Waqf (2013), there were 1,850 mosques in the West Bank. Of these, 50 were under construction. The areas of these mosques amounted to more than 765 dunams (Ministry of Waqf, 2013g).

Table 1. Areas and types of waqf land in the West Bank governorates

\begin{tabular}{|c|c|c|c|c|c|c|c|}
\hline Governorate & $\begin{array}{l}\text { Area of } \\
\text { plain } \\
\text { lands }\end{array}$ & $\begin{array}{l}\text { Area of } \\
\text { planted } \\
\text { lands }\end{array}$ & $\begin{array}{lr}\begin{array}{l}\text { Area of lands } \\
\text { used } \\
\text { construction }\end{array} & \begin{array}{r}\text { for } \\
\end{array}\end{array}$ & $\begin{array}{l}\text { Area of } \\
\text { cemetery } \\
\text { lands }\end{array}$ & $\begin{array}{l}\text { Area of } \\
\text { shrine } \\
\text { lands }\end{array}$ & $\begin{array}{l}\text { Area of } \\
\text { mosque } \\
\text { lands }\end{array}$ & $\begin{array}{l}\text { Total area of waqf } \\
\text { lands in } \\
\text { governorate }\end{array}$ \\
\hline Jenin & 755 & 452 & 104 & 668 & 9 & 162 & 2,150 \\
\hline Tubas & 69 & 41 & 3 & 6 & 40 & 14 & 173 \\
\hline Nablus & 315 & 367 & 94 & 545 & 64 & 56 & 1,441 \\
\hline Salfit & 767 & 163 & 38 & 246 & 3 & 32 & 1,249 \\
\hline Tulkarm & 682 & 667 & 114 & 546 & 4 & 67 & 2,080 \\
\hline Qalqilya & 222 & 123 & 132 & 45 & 1 & 32 & 555 \\
\hline Ramallah & 4,318 & 458 & 372 & 597 & 52 & 77 & 5,874 \\
\hline $\begin{array}{l}\text { Jerusalem } \\
\text { villages }\end{array}$ & 1,968 & 264 & 130 & 246 & 27 & 32 & 2,667 \\
\hline Bethlehem & 1,725 & 554 & 252 & 90 & 10 & 59 & 2,690 \\
\hline Jericho & 145,401 & 3,750 & 254 & 188 & 2 & 19 & 149,614 \\
\hline Hebron & 340 & 196 & 490 & 173 & 29 & 136 & 1,364 \\
\hline $\begin{array}{l}\text { Dura and } \\
\text { Yatta }\end{array}$ & 598 & 30 & 6 & 52 & 150 & 79 & 915 \\
\hline Grand total & 157,160 & 7,065 & 1,989 & 3,402 & 391 & 765 & 170,772 \\
\hline
\end{tabular}

\section{Uses of Waqf Lands in the West Bank Governorates}

While examining the economic efficiency of investment in waqf lands, it should be maintained that all waqf land cannot be subjected to the criteria of this study because the lands of the shrines, the cemeteries and mosques are earmarked for public utility, and charitable work. Therefore, these lands cannot be used in any of waqf investment versions. So only waqf lands that are appropriate for agricultural and real estate investment will be used in investment versions. In this context, these lands amounted to 166,214 dunams. To get an accurate picture of the current state of affairs of waqf lands, in terms of their use, they have been classified, according to type and use, into two types: plain lands and planted lands. The researcher has classified each type, according to its use, into two types: leased and non-leased. Results of this classification have been tabulated.

\subsection{Current State of Affairs of Waqf Lands in Jenin Governorate}

Jenin Governorate is considered one of the richest agricultural governorates (Abu Zaid, 2013). The waqf administration owns 1,311dunams all suitable for agricultural, industrial, real estate and tourism investment. Of these, 754 dunams (58\% of all plain waqf lands in the governorate), and 452 dunams (34\%) were planted with fruit bearing trees (Jenin Waqf Directorate, 2013a).

The Jenin Waqf Directorate leases all its plain lands on the basis of seasonal agricultural contracts. However, in spite of the abundance of plain lands in this governorate, only $42.5 \%$ was leased in 2013. This has been negatively reflected on the return from plain lands. Only $8 \%$ of the plane lands were leased for public utilities. However, $75 \%$ of planted plain lands were leased seasonally in return for a percentage of produce (Jenin Waqf Directorate, 2013a). The percentage of planted lands increased in 2000 because of the Ministry of Waqf's new policy to plant more trees in plain lands through conclusion of long-term mugharasah (tree plantation) agreements (Jenin Waqf Directorate, 2013b).

Generally, the area of all invested lands in Jenin Governorate amounted to $58.4 \%$ of all waqf lands. Table 2 shows results of analysis of descriptive data of waqf land according to type and form of use. 
Table 2. Use of waqf lands in Jenin governorate (according to type)

\begin{tabular}{llll}
\hline Type of land and form of investment & Number of holdings & Area in dunams & Total number of dunams \\
\hline Leased plain lands & 16 & 321 & 321 \\
Non-leased plain lands & 52 & 433 & 754 \\
Leased planted lands & 62 & 340 & 1094 \\
$\begin{array}{l}\text { Non-leased planted lands } \\
\text { Lands exploited }\end{array}$ & 14 & 112 & 1206 \\
construction/public utilities & 31 & 105 & 1311 \\
\hline
\end{tabular}

\subsection{Current State of Affairs of Waqf Land Investment in Tubas Governorate}

Unlike Jenin Governorate, Tubas Governorate owns small holdings of lands despite the abundance of agricultural lands in it (Yaqoub, 2013). The Waqf Directorate owns 113 dunams all appropriate for investment. Of these, 69 dunams were plain lands, while 41 dunams were planted with trees (Tubas Waqf Directorate, 2013). After making analysis of occupancy in this governorate, it was found that $57 \%$ of the area of plain land was leased as opposed to only $36 \%$ of leased planted lands. Only $2.6 \%$ of the area was used for real estate purposes. Therefore, the occupancy amounted to $50.4 \%$ of the total waqf lands. This is indeed a low percentage. The lands allocated for charitable purposes, such as mosques, and cemeteries for Muslims, amounted to $29 \%$.

Table 3. Type of waqf land occupancy in Tubas governorate

\begin{tabular}{lllll}
\hline Type of land and form of investment & $\begin{array}{l}\text { Number } \\
\text { holdings }\end{array}$ & of $\begin{array}{l}\text { Area } \\
\text { dunams }\end{array}$ & in & $\begin{array}{l}\text { Total } \\
\text { dunams }\end{array}$ \\
\hline Leased plain lands & 2 & 39 & 39 \\
Non-leased plain lands & 4 & 30 & 69 \\
Leased planted lands & 4 & 15 & 84 \\
Non-leased planted lands & 3 & 26 & 110 \\
$\begin{array}{l}\text { Land used for construction of building/public } \\
\text { utilities }\end{array}$ & 3 & 3 & 113 \\
\hline
\end{tabular}

\subsection{Waqf Land Investment in Nablus Governorate}

It was found that the Islamic Waqf in Nablus owned 776 dunams, all suitable for both agricultural and real estate investment (Nablus Waqf Directorate, 2013a). Of these, 315 dunams were plain lands or $40.6 \%$ of all waqf lands in the governorate, 367 dunams were planted with fruit bearing trees or $47.3 \%$ of all waqf lands in the governorate (Nablus Waqf Directorate, 2013b). In addition, there were 12 dunams hoarded for waqf employees' housing project (Nablus Waqf Directorate, 2013c).

Results of occupancy analysis show that the percentage of lease of waqf lands in Nablus Governorate was low. It failed to exceed $9 \%$ in plain areas. In planted lands, the lease rose to $50 \%$. Lands leased for building public utilities stood at $12 \%$. Those results show that more than $70 \%$ of waqf agricultural lands in Nablus area were not exploited.

Table 4. Type of occupancy of waqf lands in Nablus governorate

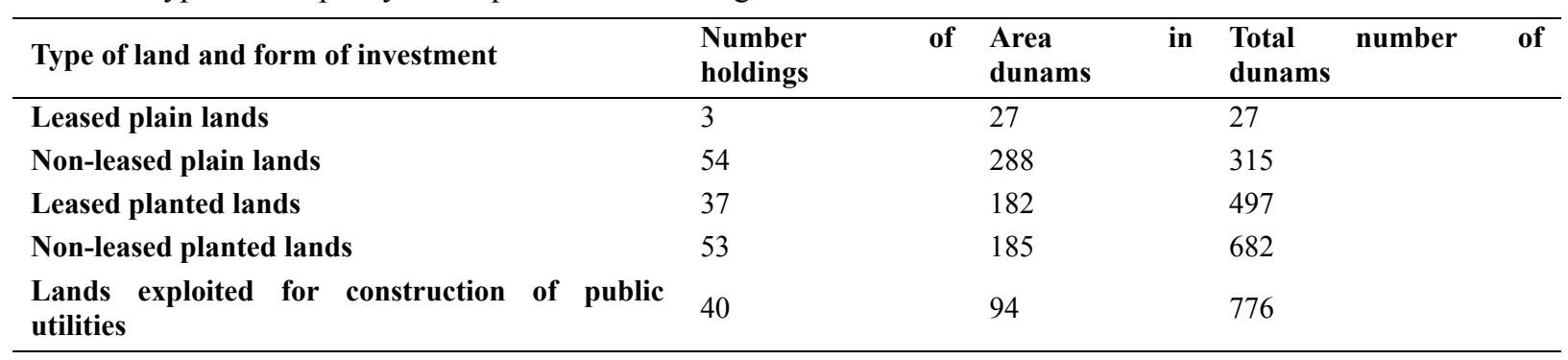




\subsection{Waqf Land Investment in Salfit Governorate}

The results of this study showed that the overwhelming majority of waqf lands in Salfit Governorate were plain. The total area amounted to 767 dunams or $79.2 \%$ of all waqf lands (968 dunams). In contrast, the area of planted land amounted to 163dunams or $16.8 \%$ of the total area of waqf lands (Salfit Waqf Directorate, 2013).

The results of this study also showed that only $80 \%$ of plain lands were leased in 2013 as opposed to the lease of $64 \%$ of tree-planted lands due to its seasonal lease in return for their produce. The Waqf Directorate allocated $4 \%$ for real estate investment.

Table 5. Type of occupancy of waqf Land in Salfit governorate

\begin{tabular}{|c|c|c|c|}
\hline Type of land and form of investment & $\begin{array}{l}\text { Number } \\
\text { holdings }\end{array}$ & $\begin{array}{l}\text { Area } \\
\text { dunams }\end{array}$ & $\begin{array}{ll}\text { Total } & \text { number } \\
\text { dunams } & \end{array}$ \\
\hline Leased plain lands & 5 & 62 & 62 \\
\hline Non-leased plain lands & 70 & 705 & 767 \\
\hline Leased planted lands & 37 & 104 & 871 \\
\hline Non-leased planted lands & 10 & 59 & 930 \\
\hline $\begin{array}{l}\text { Lands exploited for construction of public } \\
\text { utilities }\end{array}$ & 16 & 38 & 968 \\
\hline
\end{tabular}

\subsection{Waqf Land Investment in Tulkarm Governorate}

Like Jenin Governorate, Tulkarm is the home to very rich agricultural lands (Al Hassan, 2013). The Waqf Directorate owns 1,463 dunams, all suitable for investment. Of these, 682 dunams (46.6\%) are plain as opposed to 667 dunams (45.6\%) planted with fruit bearing trees. (Tulkarm Waqf Directorate, 2013).

The results of the study showed that only $35 \%$ of plain lands were leased in 2013 as opposed to more $89 \%$ of planted lands. It was also found that the Waqf Directorate has exploited $4 \%$ of its lands in real estate investment.

Table 6. Type of occupancy of waqf lands in Tulkarm governorate

\begin{tabular}{|c|c|c|c|}
\hline Type of land and form of investment & $\begin{array}{l}\text { Number } \\
\text { holdings }\end{array}$ & $\begin{array}{l}\text { Area in } \\
\text { dunams }\end{array}$ & $\begin{array}{l}\text { Total number } \\
\text { dunams }\end{array}$ \\
\hline Leased plain lands & 58 & 240 & 240 \\
\hline Non-leased plain lands & 33 & 442 & 682 \\
\hline Leased planted lands & 175 & 597 & 1,279 \\
\hline Non-leased planted lands & 7 & 70 & 1,349 \\
\hline $\begin{array}{l}\text { Lands exploited for construction of public } \\
\text { utilities }\end{array}$ & 45 & 114 & 1,463 \\
\hline
\end{tabular}

\subsection{Waqf Land Investment in Qalqilya Governorate}

Results of this study showed that the Waqf Directorate's share of agricultural lands was small (Abu Al Dike, 2013). It amounted to 390 dunams. The vast majority of these lands were plain areas: 222 dunams or $56.9 \%$. In contrast, the tree-planted areas amounted to 123 dunams or $23 \%$ of all waqf lands (Qalqilya Waqf Directorate, 2013).

The results of the study also showed that the occupancy of waqf lands was very low (Qalqilya Waqf Directorate, 2013). Only $11 \%$ of plain lands were leased in 2013 as opposed to the lease of $43 \%$ of tree-planted lands. More than $8 \%$ of waqf lands were allocated for the building of official institutions on them.

Table 7. Type of occupancy of waqf land in Qalqilya governorate

\begin{tabular}{llll}
\hline Type of land and form of investment & Number of holdings & Area in dunams & $\begin{array}{l}\text { Total number } \\
\text { of dunams }\end{array}$ \\
\hline Leased plain lands & 2 & 21 & 21 \\
Non-leased plain land & 24 & 201 & 222 \\
Leased planted lands & 5 & 54 & 276 \\
Non-leased planted lands & 9 & 69 & 345 \\
Lands exploited for construction of public utilities & 15 & 45 & 390 \\
\hline
\end{tabular}




\subsection{Waqf Land Investment in Ramallah Governorate}

Ramallah-Al Bireh Governorate, the political and administrative hub of the Palestinian National Authority, is one of the richest West Bank governorates in waqf property (Daqa, 2013). The total area of waqf lands appropriate for investment amounted to more than 5,148 dunams. The vast majority of this land was plain (4,318 dunams) or $84 \%$ of all waqf lands in the governorate. In contrast, the tree-planted lands represented about $8 \%$ (Ramallah Waqf Directorate, 2013).

Despite the abundance of plain lands in Ramallah-Al Bireh Governorate, their exploitation was very low. It failed to exceed $4 \%$ of all plain lands. Only $4.5 \%$ of tree-planted lands were leased in the governorate. However, the land used for the building of public utilities in the governorate increased to $7.2 \%$.

Table 8. Type of occupancy of waqf land in Ramallah-bireh governorate

\begin{tabular}{|c|c|c|c|}
\hline Type of land and form of investment & $\begin{array}{l}\text { Number } \\
\text { holdings }\end{array}$ & $\begin{array}{l}\text { Area in } \\
\text { dunams }\end{array}$ & $\begin{array}{l}\text { Total number } \\
\text { dunams }\end{array}$ \\
\hline Leased plain lands & 19 & 166 & 166 \\
\hline Non-leased plain land & 561 & 4,152 & 4,318 \\
\hline Leased planted lands & 7 & 21 & 4,339 \\
\hline Non-leased planted lands & 55 & 437 & 4,776 \\
\hline $\begin{array}{l}\text { Lands exploited for construction of public } \\
\text { utilities }\end{array}$ & 103 & 372 & 5,148 \\
\hline
\end{tabular}

\subsection{Waqf Land Investment in Jerusalem and Its Suburbs}

Jerusalem is well known as an exclusively waqf city (Salahat, 2011). Its waqf is also diverse: charitable and dhuri (family-endowed property). The area of Al-Aqsa Mosque amounts to 144 dunams and it is all waqf property (Sabri, 1998). According to Jerusalem Waqf General Administration Records, the area of the old city, within the Jerusalem wall, amounts to 900 dunams. Of these, 450 dunams are Islamic waqf, 317 dunams are waqf for the Orthodox Church; 83 dunams are waqf for the Catholic Church and 50 dunams are waqf for the Anglican Church (Salahat, 2011).

The area of the waqf land amounts to 2,362 dunams. The vast majority of the land was plain (1,968 dunams) while the tree-planted lands did not exceed 264 dunams (Jerusalem Waqf Department, 2013).

The findings of the study showed that the percentage of lease in Jerusalem was very low. Only $3.8 \%$ of plain lands were leased in 2013. However, the leasing of tree-planted lands in 2013 rose to 66\%. The Waqf Department allocated $5.6 \%$ of its land for real estate investment.

Table 9. Type of occupancy of the waqf land in Jerusalem Suburbs

\begin{tabular}{|c|c|c|c|}
\hline Type of land and form of investment & $\begin{array}{l}\text { Number } \\
\text { holdings }\end{array}$ & $\begin{array}{l}\text { Area in } \\
\text { dunams }\end{array}$ & $\begin{array}{l}\text { Total number } \\
\text { dunams }\end{array}$ \\
\hline Leased plain lands & 6 & 74 & 74 \\
\hline Non-leased plain land & 106 & 1,894 & 1,968 \\
\hline Leased planted lands & 16 & 174 & 2,142 \\
\hline Non-leased planted lands & 7 & 90 & 2,232 \\
\hline $\begin{array}{l}\text { Lands exploited for construction of public } \\
\text { utilities }\end{array}$ & 46 & 130 & 2,362 \\
\hline
\end{tabular}

\subsection{Waqf Land Investment in Bethlehem Governorate}

It's worth noting that most of Bethlehem and Beit Jalah lands were waqf according to official records and waqf deeds date back to the Ottoman rule (Bethlehem Waqf Directorate, 2013a). However, with the passing of time, most of this waqf land turned into private property. According to Bethlehem Waqf Directorate's records (2013), only 2,531 dunams have remained. Of these, 1,725 dunams (68\%) were plain, and 554 dunams (22\%) were planted with trees. (Bethlehem Waqf Directorate, 2013b)

The results of this study indicated that waqf lands suffered from low occupancy (A'aiesh, 2013). It was found 
that only $8 \%$ of the area of plain lands was leased in 2013 as opposed to $27 \%$ of tree-planted lands. Around $10 \%$ was allocated for real estate investment and public utilities such as schools and industrial and tourism enterprises (Bethlehem Waqf Directorate, 2013b). This low occupancy of plain lands in the governorate was due to numerous assaults on the waqf property. According to Bethlehem Waqf Directorate (2013), 669 dunams were expropriated (Bethlehem Waqf Directorate, 2013c).

Table 10. Type of occupancy of waqf land in Bethlehem governorate

\begin{tabular}{llll}
\hline Type of land and form of investment & Number of holdings & Area in dunams & Total number of dunams \\
\hline Leased plain lands & 6 & 208 & 208 \\
Non-leased plain lands & 51 & 1,517 & 1,725 \\
Leased planted lands & 15 & 151 & 1,876 \\
Non-leased planted lands & 19 & 403 & 2,279 \\
Lands exploited for construction/ public utilities & 20 & 252 & 2,531 \\
\hline
\end{tabular}

\subsection{Investment of Waqf Land in Jericho Governorate}

Jericho Governorate is considered a treasure of waqf lands for the Ministry of Waqf (Mansour, 2013). The area of waqf land amounts to 149,405 dunams. Except for 3,750 dunams planted with palm trees, all waqf land in Jericho is plain (Ministry of Waqf, 2013h). The lands suitable for agricultural investment amounts to 48,740 dunams. All this area is suitable for plantation of palm trees, grapes and others. Unfortunately, it has not been exploited until now. (Jericho Waqf Directorate, 2013a).

The Waqf Directorate has allocated more than 253 dunams for construction of buildings for institutions and security offices for the Palestinian National Authority. (Jericho Waqf Directorate, 2013b).

The analysis of data showed that less than $3 \%$ of waqf land was leased in Jericho whether for agricultural activity or real estate. One reason for this low percentage of leased lands was due to absence of an investment policy for Ministry of Waqf to depend on its own resources to invest its land by planting it with palm and grape trees. The policy of the Ministry of waqf has been to depend on partnership with the private sector (AL-Zaghari, 2013). Another reason was the numerous assaults on waqf lands by the Israeli occupation which has confiscated more than 102,831 dunams for the sake of "security" purposes and settlement projects (Jericho Waqf Directorate, 2013c).

Table. 11 Occupancy of waqf land in Jericho governorate

\begin{tabular}{llll}
\hline Types of land and form of investment & Number of holdings & Area in dunams & $\begin{array}{l}\text { Total number } \\
\text { of dunams }\end{array}$ \\
\hline Leased plain lands & 40 & 648 & 648 \\
Non-leased plain lands & 134 & 144,745 & 145,401 \\
Leased planted lands & 37 & 3,750 & 149,151 \\
Non-leased planted lands & 0 & 0 & 149,151 \\
Lands exploited for construction of public utilities & 18 & 254 & 149,405 \\
\hline
\end{tabular}

\subsection{Investment of Waqf Land in Hebron Governorate}

The results of this study showed that Ministry of Waqf owned more than 547 dunams. Of these, 340 dunams $(62 \%)$ were plain, and 196 dunams $(36 \%)$ were planted with trees. The waqf exploited 11 dunams for the building of public facilities. Around 201 dunams were allocated for charitable deeds. These included cemeteries for Muslims, shrines and archaeological ruins (Hebron Waqf Directorate, 2013).

As the results of this study indicate in nearly all governorates, the rate of occupancy in waqf land is low (Mansour, 2013) . The rate of occupancy in Hebron Governorate didn't exceed 6\% of plain lands and 54\% of tree planted lands. In the real estate sector, occupancy rate was about $2 \%$. 
Table 12. Type of occupancy of waqf lands in Hebron governorate

\begin{tabular}{llll}
\hline Type of land and form of investment & Number of holdings & Area in dunams & $\begin{array}{l}\text { Total numbe } \\
\text { of dunams }\end{array}$ \\
\hline Leased plain lands & 15 & 21 & 21 \\
Non-leased plain land & 52 & 319 & 340 \\
Leased planted lands & 6 & 106 & 446 \\
Non-leased planted lands & 5 & 90 & 536 \\
Lands exploited for construction of public utilities & 3 & 11 & 547 \\
\hline
\end{tabular}

\subsection{Investment of Waqf Land in Dura and Yatta Governorates}

The results of this study showed that all waqf lands in Dura and Yatta were plain. The area of this land amounted to about 634 dunams. There were no tree-planted areas except 30 dunams planted in cooperation with Dura Municipality. (Dura Waqf Directorate, 2013). The results of analysis also showed that the occupancy rate was very low and did not exceed $6 \%$ of all waqf lands. The main reason for this low occupancy rate was the Israeli settlement expansion in the governorate. Vast areas have been confiscated for military and other purposes. (Dura Waqf Directorate, 2013).

Table 13. Type of occupancy of waqf land in Dura and Yatta

\begin{tabular}{llll}
\hline Type of land and form of investment & Number of holdings & Areas in dunams & $\begin{array}{l}\text { Total number } \\
\text { of dunams }\end{array}$ \\
\hline Leased plain lands & 4 & 44 & 43 \\
Non-leased plain lands & 11 & 554 & 598 \\
Leased planted lands & 1 & 30 & 628 \\
Non-leased planted lands & 0 & 0 & 628 \\
Lands exploited for construction of public utilities & 0 & 6 & 634 \\
\hline
\end{tabular}

\section{Investment Efficiency of Waqf Land in the West Bank}

Despite the establishment of the Palestinian National Authority and the creation of a ministry of waqf to be in charge of developing the waqf properties, the efficiency of investment of waqf lands in the West Bank has remained very poor. Most of the waqf land has remained neglected and revenues have consequently remained meager particularly in plain areas.

\subsection{Role of the Ministry of Waqf in Investment of Waqf Lands}

To make a judgment on the efficiency of investment of waqf lands, one has to identify most important forms of investment employed by the Ministry of Waqf.

\subsubsection{In the Agricultural Sector}

The ministry of waqf has employed a number of investment forms to lease the plane lands. One of these form is "muzara'ah" and "mugharasah" (crop-sharing and tree plantation accordingly). These are two common methods used in agricultural areas of countries which depend on agriculture. From a fiqh perspective, fiqh scholars see no problem in concluding muzara'ah and mugharasah contracts in waqf lands as long as such practice is of benefit to the waqf establishment, on one hand, and it precludes from keeping the land unused and poor, on the other hand. When kept unused, the purpose of making it waqf is also impeded (Ibn Azouz, 2003). Accordingly, plain waqf lands were contracted through muzara'ah $(1,017)$ dunams (Ministry of Waqf, 2013i) a very low amount, in comparison with the area of plain lands in the West Bank. Traditionally, the Ministry of Waqf concludes "muzara'ah" contracts by offering plain lands to another party to invest in it through growing seasonal crops in return for low fees agreed upon according to suitability of the land for agricultural use (Makki, 1979).The fees ranged between 5-15 Jordanian dinars per dunam. This amount is undoubtedly very low. However, despite this low return from plain lands, one cannot underestimate the efficiency and productivity of this muzara'ah practice to meet the society food security needs and to create jobs for those who do not have land. In that way, they achieve their investment ambitions (Naser, 1998).

Since 2000, the Ministry of Waqf has had a new policy of mugharasah (plantation) in lieu of seasonal muzara'ah. This has increased the percentage of land planted with trees in the West Bank. In this kind of investment, the 
waqf establishment concludes an agreement with an economic partner who agrees to plant the land of waqf with fruit bearing trees, such as olive trees, in mountain areas, or palm trees and grape trees in Jericho area. The waqf share is usually determined in cash or percentage of produce during the contract term according to lifetime of the trees. Usually, the fees are gradual. In the first few years of the contract, the tenant is exempted from paying these fees because the trees would be young and unfruitful yet. Then the fees are determined/fixed and are raised in subsequent years according to lifetime of trees (Abed, 2013). After expiry of contract, the invested land and the trees planted in it are returned to the waqf establishment.

It is crystal clear that the Ministry of Waqf has depended in investment of its assets (lands), on an economic partner who usually applies to tile a plot of land to plant it or grow it according to terms set by the ministry in the agreement. The ministry has not depended, in investment of land resources, on its own efforts through establishment of agricultural engineering department and a setting up of a national strategy for the investment of its waqf lands in all fields (Dweikat, 2013).

Table 14. Investment of waqf plain land in mugharasah agreements

\begin{tabular}{lllll}
\hline Type of trees & $\begin{array}{l}\text { Number of } \\
\text { contracts }\end{array}$ & Area in dunams & $\begin{array}{l}\text { Duration of } \\
\text { Contract in years }\end{array}$ & $\begin{array}{l}\text { Return in Jordainan } \\
\text { dinars }\end{array}$ \\
\hline Palm trees & 33 & 3,808 & 25 & 159,817 \\
Olive trees & 31 & 404 & 18 & Percentage of produce \\
Stone fruit trees & 15 & 371 & 16 & Percentage of produce \\
Guava trees & 3 & 26 & 18 & Percentage of produce \\
Fig trees & 2 & 3.5 & 18 & Percentage of produce + amount of money \\
Lemon trees & 3 & 43 & 18 & Percentage of produce \\
\hline
\end{tabular}

Source: Ministry of Waqf, 2013, Waqf Property Registry

\subsubsection{In the Construction Sector}

This sector has drawn wide interest from the Ministry of Waqf because it's an investment that generates high rate of return which in turn is invested in other waqf projects. This construction sector contributes to the waqf system by guaranteeing a significant part of durable goods (facilities), thus advancing the different needs of social welfare of the society. According to the Ministry of Waqf (2013), 1,989 dunams were invested in this sector (Ministry of Waqf, 2013j). However, this was a very low percentage in comparison with the area of plain lands. To invest its lands in the construction sector, the Ministry of Waqf has adopted a number of investment forms:

1) Partnership ending in ownership

This form of partnership, ending in ownership, is one of the suitable contemporary financing versions to develop real estate projects. It is a short-term form of financing and investment ending in ownership. It is mainly based on leasing the waqf land to an investor who in turn would develop it and exploit it for a fixed period of time on condition that its ownership, upon expiry of lease, be returned to waqf. (Al-Amer, 2007). A case in point, in this context, is Sufian Tower Project in Nablus (Nablus Waqf Directorate, 2013d).

2) Partnership with financial institutions like the Islamic Development Bank

In this kind of investment, the waqf establishment asks the bank for the financing of a certain project and submits the relevant economic feasibility, engineering studies and the method of repayment. The loan is usually repaid from the revenues of the project. One example of such a project is waqf's Al-Bireh Towers Project. The Ministry of Waqf is working currently to implement it (Ministry of Waqf, 2013k).

\subsubsection{In the Tourism Sector}

Despite the availability of lands for tourism-related projects, particularly in Jericho area (Al-Zaghari, 2013), and the presence of 393 shrines (historical and religious) in the West Bank, which can be used for tourism activities ,(Ministry of Waqf, 20131), there is still a poor interest and investment in this sector. For example, most of these shrines are demolished and deserted and lack easy access to them. Therefore, these shrines need a serious interest and a national strategic tourism plan to tap their potentials as many of them are located in very attractive areas.

\subsection{Percentage of Lands Exploited in the Economic Sectors}

The statistical analysis of the collected data about investment percentages revealed the following. 


\subsubsection{Agricultural Sector}

The percentage of leased planted lands in the agricultural sector was very low in the West Bank governorates. In Tubas governorates, $57 \%$ of all plain lands of waqf was leased as opposed to $42.5 \%$ in Jenin, $35 \%$ in Tulkarm, $11 \%$ in Qalqilya, $9 \%$ in Nablus, $8 \%$ in Salfit, $8 \%$ in Bethlehem, $7.8 \%$ in Dura and Yatta $6 \%$ in Hebron, $4 \%$ in Ramallah, 3.8\% in Jerusalem Suburbs and less than $0.5 \%$ in Jericho. Occupancy of all plain lands was only $1.6 \%$ due to the fact that $92 \%$ of all plain lands of waqf in the West Bank are located in Jericho. Consequently, this has led to sharp drop in exploitation of plain lands. This in turn has negatively affected the revenues from waqf properties and the extent of their contribution to the Palestinian national economy and protection of food security in the West Bank (Ministry of Waqf, 2013m).

In contrast to plain lands, the percentage of investment in plantation was found to be much higher. Most of planted lands were leased according to percentage of fruit produce. The highest percentage of investment in planted lands was recorded in the north of the West Bank. About $89 \%$ of all planted lands in Tulkarm were leased in 2013 as opposed to $75 \%$ in Jenin, $66 \%$ in Jerusalem Suburbs, $64 \%$ in Salfit, 54\% in Hebron, 50\% in Nablus, 34\% in Qalqilya, 36\% in Tubas, $27 \%$ in Bethlehem and 4.5\% in Ramallah (Ministry of Waqf, 2013n).

\subsubsection{Construction/Building Sector}

The highest percentage of lease of plain lands (12\%) in the real estate sector was recorded in Nablus Governorate as opposed to $10 \%$ in Bethlehem, $5.6 \%$ in Jerusalem suburbs, $4 \%$ in Tulkarm, $4 \%$ in Salfit, 2.6\% in Tubas, $2 \%$ in Hebron, and less than $0.1 \%$ in Jericho. Occupancy rate in all the West Bank was $1.2 \%$ because most of plain lands concentrate in Jericho Governorate which has $92 \%$ of all plain lands in the West Bank (Mansour, 2013).

\subsection{Reasons for Low Investment of Waqf Lands}

One can infer from these statistics in question that most of waqf lands (94\% of all plain lands and $54 \%$ of all planted lands) in the West Bank were unexploited. This very poor investment and exploitation of waqf lands can be attributed to a number of factors. First, the waqf lands sector in the West Bank had significantly dwindled in previous decades. This contraction in the area of waqf lands can be attributed to both local and Israeli occupation assaults on waqf lands. For example, residents of Bethlehem Governorate have taken control of over 600 dunams of waqf lands due to old contracts and hoarding (Bethlehem Waqf Directorate, 2013a). The Israeli occupation authorities have also expropriated more than 104,996 dunams of waqf lands. Most of it was in Jericho Governorate. (Ministry of Waqf, 2013a).

Most of plain lands of waqf were unsuitable for agricultural purposes due to their presence on tops of mountains or valleys; this is in addition to the lack of roads to them and the high cost of their reclamation. Therefore, the Ministry of Waqf has so far refrained from setting up a strategic plan to reclaim these lands and invest in them. (Eshtayyeh et al., 2006).

The Ministry of Waqf has always depended, in investment of its plain lands, on partnership with the private sector whether in the agricultural or construction sector. This investment policy has decreased opportunities for investment in unused lands. (Mansour, 2013).

A significant portion of agricultural lands was small in size; for example, the waqf land area of less than one dunam represented $25 \%$ of waqf land. That means $25 \%$ of plain land didn't have investment attraction, thus making it unattractive for investment by the private sector. In contrast, waqf holdings of one-five dunams represented $30.4 \%$ of waqf land. These holdings enjoy investment attraction and this applies to all holdings of more than five dunams.

Table 15. Distribution of waqf lands in the West Bank

\begin{tabular}{lll}
\hline Area in dunams & Number of holdings & \% \\
\hline Less than 0.5 dunam & 95 & $12.7 \%$ \\
0.5-less than one dunam & 91 & $12.11 \%$ \\
1-Less than 5 dunams & 230 & 30.7 \\
5-Less than to dunams & 95 & 12.7 \\
Bigger or equal to 10 dunams & 183 & 24.4 \\
Unavailable & 55 & 7.4 \\
Total & 749 & 100 \\
\hline
\end{tabular}


Most of plain land is located in Area C (60\% of the West Bank), and in Jericho city in particular. This location creates obstacles for its investment due to Israeli military control of this area, let alone the presence of Jewish settlements on it or due to its location behind the Apartheid Wall, thus precluding its use (Eshtayyeh et al., 2013).

\section{Results}

1) There were empty waqf real estate projects and unused lands. This has left negative effects on the returns of waqf properties and the extent of their contribution to the Palestinian economy and national development projects.

2) There was a variety in waqf lands. Some of them are suitable for investment and these include plain lands (92\%), planted lands (41\%). Other lands are suitable for real estate investment $(1.2 \%)$. This is in addition to lands allocated for public utility and these include cemeteries, mosques, shrines $(2.7 \%)$. In other words, the area of waqf lands, suitable for investment, amounts to 166,214 dunams or $97.3 \%$ of all waqf lands. Unfortunately, most of it is neglected.

3) This study found that the percentage of plain lands leased for agricultural purposes in the West Bank governorates was very low. It was $57 \%$ of all plain lands in Tubas Governorate compared to $42.5 \%$ in Jenin, $35 \%$ in Tulkarm, $11 \%$ in Qalqilya, $9 \%$ in Nablus, $8 \%$ in Salfit, $8 \%$ in Bethlehem, $7.8 \%$ in Dura and Yatta, $6 \%$ in Hebron, $4 \%$ in Ramallah, 3.8\% in Jerusalem suburbs, and less than $1 \%$ in Jericho. This has hit hard the returns of waqf property and the extent of its contribution to the Palestinian national economy and food security in particular.

4) This study has also showed that the percentage of plain lands leased for the construction sector in the West Bank governorates was relatively low. In Nablus, $12 \%$ of plain lands was leased in comparison with $10 \%$ in Bethlehem, $8 \%$ in Jenin, $8 \%$ in Qalqilya, $7.2 \%$ in Ramallah, $6 \%$ in Jerusalem Suburbs, $4 \%$ in Tulkarm, $4 \%$ in Salfit, $2.6 \%$ in Tubas, $2 \%$ in Hebron, and less than $0.1 \%$ in Jericho. Due to the concentration of plain lands in Jericho area, $92 \%$ of all plain area in the West Bank, the occupancy rate in the construction sector in the West Bank failed to exceed $1.2 \%$.

5) This study has also found that the percentage of planted lands leased in the West Bank was higher than its counterpart in plain lands. It was found that $89 \%$ of planted lands in Tulkarm were leased in 2013 as opposed to $75 \%$ in Jenin, $66 \%$ in Jerusalem suburbs, $64 \%$ in Salfit, $54 \%$ in Hebron, $50 \%$ in Nablus, $43 \%$ in Qalqilya, $36 \%$ in Tubas, $27 \%$ in Bethlehem, $4.5 \%$ in Ramallah. The highest percentage of lease of planted lands was in northern West Bank.

6) The waqf lands sector in the West Bank has seen a significant downturn since 1997 due to the frequent assaults on waqf lands by the Israeli military occupation for settlement expansion and establishment of military zones. This was in addition to residents' exploitation of the old contracts (hoarding) to control waqf lands particularly in Jerusalem and Bethlehem.

7) In the last ten years, the waqf lands sector has seen a slight increase in waqf land investment, thanks to the Ministry of Waqf's new policy of investment in plain lands through mugharasah plantation contracts or through construction contracts. The returns of planted lands and real estate investment were much more those of seasonal agriculture.

8) It was found that investment in waqf projects and transformation of unused lands to development productive projects would generate steady income which in turn would secure decent life for cross-sections of the Palestinian society. Figh scholars have upheld legitimacy of waqf investment and development, and expansion of its proceeds to provide better services and realize the purposes of its creation: meeting the interest of the public and individuals.

9) In principle, all waqf projects are non-profit. However, there is a trend now to achieve returns as a means to cover the expenditures of waqf in terms of construction and maintenance. Therefore, the waqf plays an effective role in developing the national resources through investment and production projects. However, this role is taking a different direction. The waqf resources are almost impeded and frozen and remain untapped.

10) The efficiency of investment of waqf property was very low. Productivity in the waqf sector was low due to absence of a modern investment administration. The waqf administration has low academic qualifications and poor investment experience.

11) The West Bank was home to more than 393 shrines occupying 391 dunams. Most of these shrines were suffering from negligence. The majority have been demolished and deserted and lacked easy access to them. All this shows the extent of lack of interest in these shrines. 


\section{Recommendations}

1) There is a necessity to make active use of unused waqf lands and reinvest them in vital sectors. This applies to waqf lands in Jericho and northern West Bank. Therefore, the waqf authorities have to adopt a new policy concerning investment of its land resources. This can be through self-investment by establishing new departments or specialized companies in its investment department. These companies could be real estate, agricultural, tourism and industrial. The Ministry of Waqf can participate with the private sector to learn from its experience on condition that waqf right of ownership of land remains.

2) There is a need to set up a comprehensive national plan to invest in unused waqf lands in Jericho Governorate through promotion of small agricultural enterprises in which a group of farmers participate. Agricultural societies can be formed with necessary government support. This is in addition to setting up engineering plans and studies for lands that can be used for real estate investment and advertising them to encourage investors in the private sector to participate in it.

3) There is a necessity to produce a manual for investment of Islamic waqf resources of various types. This can be by offering lands suitable for real estate investment, agricultural investment, industrial investment, or tourism investment coupled with proposed projects for implementation. This would encourage investors to participate in one of the different investment forms to finance projects. The ministry should provide appropriate which has experience in investment.

4) The ministry has to search for private sectors to support the would-be strategic and occupancy plan with necessary expertise and financing. This is in addition to awarding them concessions in harmony with the investment law which includes tax incentives/exemptions in order to allow the waqf administration to exploit and develop waqf properties in a better way.

5) The ministry of waqf has to study modern investment methods for waqf resources. It can learn a lot from the experiences of Muslim countries and apply them in Palestine. Decreasing lease and manufacturing are two cases in point. It should be pointed out here that the waqf plans have to be formulated in the light of the available resources and circumstances of use in projects which would generate financial and social returns at the same time.

6) The waqf projects should be linked with the goals of the national development plans. Achievement should be followed up according to efficiency and completion criteria. This would bridge the gap of structural imbalances in the national economy sectors with particular emphasis on the support of the university education sector.

7) The Lease -Rent Law effective in the West Bank should be changed in order to protect the waqf rights. Special courts need also to be established to speed up the process of looking into cases submitted against tenants of and aggressors on waqf property. These courts could be similar to labor courts approved recently. The would-be law has to includelinfer new legislations that could allow use of waqf assets to keep abreast of economic development in today's world and particularly in investment in company shares.

8) The ministry of waqf has to send short notices to hoarders and those who have failed to pay their annual hoards. These should be asked to check with the waqf ministry offices in order to organize new hoarding contracts with them in line with the texts of the Jordanian law. The ministry has also to resort to the Palestinian National Authority and its security apparatuses to protect the waqf property from this hoarding because many of these hoarders would refuse to renew the contracts. These hoarders know that the Jerusalem Waqf Department cannot resort to the Israeli courts in Jerusalem for national reasons pertinent to the waqf's non-recognition of the Israeli occupation of Jerusalem.

9) The ministry has to study new methods of investment of its natural wealth through learning from experiences of other Muslim countries and applying them in Palestine. These include manufacturing (Istisna') and decreasing lease. The waqf plans have to be formulated in the light of available resources and circumstances of use in projects that would generate both financial and social benefits.

10) The agricultural and industrial sectors should be reinforced and manufacturing industry has to be benefited from. Such industries include planting olive trees, production of soap and oil as well as processing of date and drying of grapes. In Jericho city, the waqf can rise up birds and cattle and make use of the latter's produce in making dairy products.

11) The ministry has to introduce a waqf institution to charge it with the development aspects of waqf investments. This institution would be administratively and financially independent. It is expected to reprogram the waqf lands and plan investment and identify the area of projects, according to economic feasibility criteria, and achieve maximum efficiency and administrative effectiveness possible. 
12) There is a necessity to develop the waqf returns to develop the waqf resources. The Ministry of Waqf should be asked to cover the expenditures of its various institutions like other institutions affiliated with it. These returns have to be earmarked to develop the waqf properties themselves to increase their income in the future and make use of available resources in other investment projects, thus allowing the waqf to contribute to social and economic development of the Palestinian society.

13) The ministry has to attract Islamic banks' capital to develop Islamic waqf properties on sound economic foundations whether for the purpose of reclamation of lands or construction of modern buildings.(strategic partner). It also has to implement the Waqf's Bireh Towers Project which is expected to cost 45 million dollars by depending on its own financial resources and the participation of the Islamic Development Bank and the private sector.

14) The ministry should develop/renovate the 393 religious and historic shrines in the West Bank. These shrines can be developed through a comprehensive plan and in cooperation with the Ministry of Tourism and Antiquities with the purpose of developing internal tourism and preserving their historic Islamic identity and protecting them from the Israeli confiscation and Judiasation policy.

15) A significant portion of agricultural lands was small in size, thus making them unattractive for investment by the private sector; for example the waqf land area of less than one dunam represented $25 \%$ of waqf land. That means, $25 \%$ of plain land didn't have investment attraction. The Palestinian Ministry of Waqf has to set up appropriate working plans for it, and it should invest agricultural lands by depending on its own resources.

\section{Acknowledgements}

The researcher would like to thank the Palestinian Ministry of Waqf (Endowment) for its interest, help and cooperation to give me access to its records, files and other official documents. He would like also to extend his appreciation to Mr. Sameer Mahmoud of An-Najah National University, Nablus, Palestine, for his translation and editing of this paper.

\section{References}

Abu-Sha'ar, A. (2006). Waqi' Idarat al-Aradi al-Waqfiyah fi ad-Difa al-Gharbiyah wa Alaqatoha bi Kafa'at Istithmar (p. 56). (Unpublished master's thesis). Al-Quds University, Jerusalem, Palestine.

Al-Omar, F. (2003). At-Tahadiyat al-lati Towajih Mu'asasat al-Waqf wa Tahseen al-Bina al-Mua'sasi li Muwajahatihi. Majallat Al-Waqf, 3(5), 13-41.

Attiyah, F. (2010). Tawthiq al-Waqf al-Islami li Tahqiq at-Tanmiyah fi Shamal ad-Difa al-Gharbiyah: Al-Waqi' wal Ma'mool (pp. 25-26). (Unpublished master's thesis). Al-Quds University, Jerusalem, Palestine.

Dumper, M. (1992). Islam and Israel Muslim Religious Endowments and the Jewish State (pp. 157-158). Beirut: Institute for Palestine Studies.

Eshtayyeh, M., Dory, A. A., \& Mousaa, N. (2006). Iqtisadiyat al-Waqf al-Islami fi Aradi as-Sulta al-Filistinyah (2nd ed., pp. 36-50). Ramallah, NY: publication of PECDAR.

Ibn Azouz, A. (2003). Fiqh Istithmar al-Waqf wa Tamwiloho fi il Islam. An Empirical Study of Endowment in Algiers (p. 136). Unpublished, (Unpublished docteral dissertation), University of Algiers, Algiers.

Makki, A. (1979). Tamweel al-Mashro'at fi Thil al-Islam (p. 163). Beirut: Dar al-Fikr al-Arabi.

Naser, S. (1998). Tatweer Siyagh at Tamweel Qaseer al-Ajal lil Bonook al-Islamiyah (p. 70). (Unpublished master's thesis). College of Islamic Sciences, Money and Financial Department, University of Algiers, Algiers.

Sabri, I. (1998). Al-Muqadasat wal Awqaf al-Islamiyah fi Filisteen (2nd ed., pp. 10-12). Beirut: Dar al_fikr al-Arabi.

Salahat, S. (2011). Al-Awqaf al-Islamiyah fi Filisteen wa Dawroha fi Mowajahat al-Ihtilal al-Isra'ili (pp. 89-90). Beirut: Markaz az-Zaitona li Dirasat wal Istisharat.

\section{Documents and Records}

Bethlehem Waqf Directorate (2013a). Department of Waqf Holdings, Khaski Sultan Waqf record. File \# 1-11.

Bethlehem Waqf Directorate (2013b). Department of Waqf Holdings, Record of Waqf Lands, File \# 1-111.

Bethlehem Waqf Directorate (2013c). Department of Waqf Holdings. Assaults Record, File \# 1-4.

Dura Waqf Directorate (2013a). Department of Waqf Holdings, Record of Waqf Lands, File \# 1-7. 
Dura Waqf Directorate (2013b). Department of Waqf Holdings, Assaults Record, File \# 1-4.

Hebron Waqf Directorate (2013). Department of Waqf Holdings, Record of Waqf Lands, File \# 1-146.

Jenin Waqf Directorate (2013a). Department of Waqf Holdings, Record of Waqf Lands, File \# 1-175.

Jenin Waqf Directorate (2013b). Department of Waqf Holdings, Mugharasah Agreements, File \# 1-8.

Jericho Waqf Directorate (2013a). Department of Waqf Holdings, Record of the Palm Plantations Project, (File \# $1-3)$.

Jericho Waqf Directorate (2013b). Department of Waqf Holdings, Record of Waqf Lands. File \# 1-211.

Jericho Waqf Directorate (2013c). Department of Waqf Holdings, Assaults Record. File \# 1-17.

Jerusalem Waqf Department (2013). Division of Jerusalem Waqf, Waqf Property Records, File \# 1-100.

Ministry of Waqf (2013a). Department of Waqf Property, Plain Lands Record. File \# 1-1577.

Ministry of Waqf (2013b). Department of Waqf Property, Tree-planted Lands Record. File \# 1-577.

Ministry of Waqf (2013c). Department of Waqf Property, Mugharasah Agreements Record. File \# 1-87.

Ministry of Waqf (2013d). Department of Waqf Property, Building Agreements Record. File \# 1-211.

Ministry of Waqf (2013e). Department of Waqf Property, Cemeteries Record. File \# 1-670.

Ministry of Waqf (2013f). Department of Waqf Property, Holy Shrines Record. File \# 1-393.

Ministry of Waqf (2013g). Department of Waqf Property, Mosques Record. File \# 1-1850.

Ministry of Waqf (2013h). Department of Waqf Property, Record of Palm trees lands, File \# 1-33.

Ministry of Waqf (2013i). Department of Waqf Property, muzara'ah Record, File \# 1-79.

Ministry of Waqf (2013j). Department of Waqf Property, Building Agreements; File \# 1-211.

Ministry of Waqf (2013k). Department of Waqf Property, Al-Bireh Towers Project File.

Ministry of Waqf (20131). Department of Waqf Property, Record of Waqf Lands, File \# 1-393.

Ministry of Waqf (2013m). Department of Waqf Property, Record of Plain Lands leased, File \# 1-421.

Ministry of Waqf (2013n). Department of Waqf Property, Record of Planted Lands Leased, File \# 1-373.

Nablus Waqf Directorate (2013a). Department of Waqf Holdings, Record of plain Lands, File \# 1-175.

Nablus Waqf Directorate (2013b). Department of Waqf Holdings, Waqf Lands Record, File \# 1-378.

Nablus Waqf Directorate (2013c). Department of Waqf Holdings. Hoarding File.

Nablus Waqf Directorate (2013d). Department of Waqf Holdings, Sufian Tower Project File.

Qalqilya Waqf Directorate (2013). Department of Waqf Holdings, Record of Waqf Lands, File \# 1-40.

Ramallah Waqf Directorate (2013). Department of Waqf Holdings, Tree-planted Lands Record, File \# 1-417.

Salfit Waqf Directorate (2013). Department of Waqf Holdings, Record of Planted Lands; File \# 1-138.

Tubas Waqf Directorate (2013). Department of Waqf Holdings, Record of Waqf Lands, File \# 1-16.

Tulkarm Waqf Directorate (2013). Department of Waqf Holdings, Record of Waqf Lands, File \# 1-318.

\section{Personal Interviews}

Dweikat, A. Personal interview. August 22, 2012.

Abed, M. Personal interview. August 14, 2013.

Mansour, R. Personal interview. August, 14, 2013.

Al-Zaghari, N. Personal interview. September 6, 2013.

Abdullah, M. Personal interview. September 11, 2013.

Abu Zaid, M. Personal interview. September 14, 2013.

Yaqoub, A. Personal interview. September 24, 2013.

Al Hassan, H. Personal interview. November 2, 2013.

Abu Al Dike, A. Personal interview. November 8, 2013.

Daqa, M. Personal interview. November 11, 2013. 
A'aiesh, M. A. Personal interview. November 18, 2013.

\section{Copyrights}

Copyright for this article is retained by the author(s), with first publication rights granted to the journal.

This is an open-access article distributed under the terms and conditions of the Creative Commons Attribution license (http://creativecommons.org/licenses/by/3.0/). 